\section{Discurso de la Presidenta de la Sociedad de Cirujanos de Chile en el funeral del Dr. Antonio Yuri Padua}

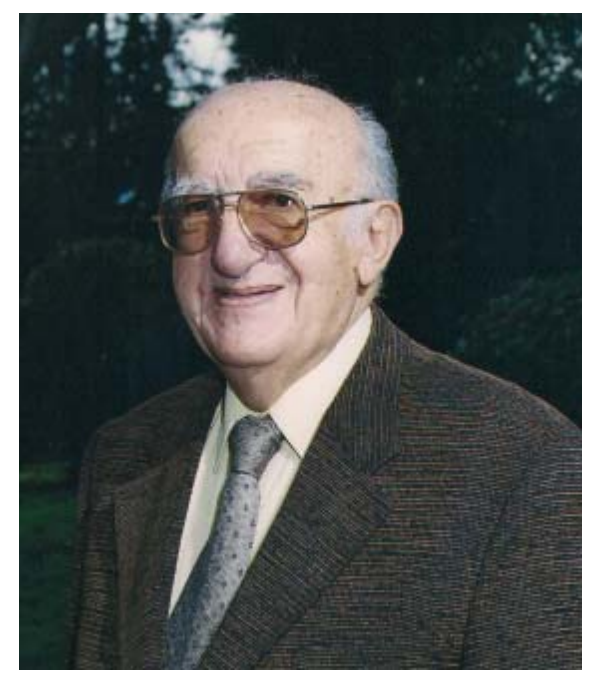

En nombre de la Sociedad de Cirujanos de Chile me ha tocado la triste y difícil misión de despedir al Dr. Antonio Yuri Padua. Triste porque siempre duele ver partir a una persona a la cual una apreciaba y respetaba, y difícil porque nunca podré plasmar en palabras el ser humano excepcional que fue el doctor Yuri.

Sus logros profesionales estuvieron siempre muy ligados a nuestra sociedad, ingresando a ella en 1955 y asumiendo su presidencia en 1979. En virtud de sus méritos fue nombrado Miembro Honorario en 1980 y Emérito en 1987.

Desempeñó el cargo de editor jefe de la Revista Chilena de Cirugía, lo que cumplió a cabalidad durante 17 años desde 1986.

Durante este ejercicio fue además, editor de 16 libros y de más de 100 cartas quirúrgicas, lo que constituyó un importante aporte para la cirugía de nuestro país y extranjera.

Pero su labor fue mucho más allá, ya que gracias a su trato personalizado, amable y respetuoso, permitió acercar a todos los cirujanos a nuestra sociedad. Cada uno de nosotros recuerda cuando nos revisaba un trabajo libre o una publicación y se preocupaba hasta de la puntuación y faltas de ortografía.

Siempre quiso que la sociedad representara a todos los cirujanos de Chile y que ojalá esto se reflejara en su directorio.

Propició y respaldó el fortalecimiento de los capítulos en regiones, siendo el testimonio más tangible de esto la compra de la sede de la V Región, destacando Don Antonio como su principal gestor.

El haber dejado el cargo de editor no lo desvinculó de su sociedad, siempre estaba presente en las reuniones mensuales y en el congreso anual. Y es ahí donde más de alguno se acercó a pedir un consejo que el respondía con mucha sabiduría.

Por todo esto y mucho más, le decimos gracias Dr. Antonio Yuri por haber sido un ejemplo como persona y como profesional para muchas generaciones de cirujanos presentes y para las que vendrán.

Doctor Yuri lo echaremos mucho de menos.

Le va hacer mucha falta a la Sociedad y a sus Cirujanos.

Dra. Jamile Camacho 